UNRAM Law Review is licensed under a Creative Commons Attribution 4.0 International License, which permits unrestricted use, distribution, and reproduction in any medium, provided the original work is properly cited. p-ISSN: 2548-9267 | e-ISSN : 2549-2365, Open Access at : http://unramlawreview.unram.ac.id/index.php/ulr Volume 5 Nomor 1 April 2021

\title{
Effectivity of Restorative Justice Meets The Just Nature of Indonesia Society
}

\author{
Ramdhani Abdul Hafidz \\ Magister of Law Program, University of Mataram \\ Email: ramdanihfz@gmail.com
Ahmad Ramdani Chairi
Magister of Law Program, University of Mataram Email: ahmadramdanichairi@gmail.com
Dirasid
Magister of Law Program, University of Mataram
Email: dirasidfhunram@gmail.com
Raka Febrian Krisnaputra
Magister of Law Program, University of Mataram
Email: rakafk@gmail.com
Irvan Ali
Magister of Law Program, University of Mataram
Email: irpanali@gmai.com

\begin{abstract}
Restorative justice is a form of cases settlement beyond the court which engaged perpetrator, victim and society as condition restore after the crime. This form started to be developed in Indonesia, especially in regions which implement "adat" law consistently and have close kinship system. Restorative justice is urgently needed today, in order to reduce the number of cases and prison over capacity. The significant number of criminal cases which had been judged in the court is the main factor of prison over capacity. The prison full of criminal which had variety of crimes. The negative impact is, prison is not a shoch-therapy for the criminals, instead of after they fulfill their sentence period and become alumni of prison, they tend to re-do their crimes even worse than the previous one. This condition was the causing factor of restorative justice in the criminal law system for example, children criminals, traffic violations which had narrow impacts and can be solved by "adat" institution, with the exception for major cases or extraordinary crimes for instance drugs, planned murder, terrorism and genocide.
\end{abstract}

Keywords: Restorative; Justice; Society; Indonesia

\section{INTRODUCTION}

Today, Indonesia remains applied an old criminal law, which inherit by the Dutch when occupied Indonesia. The law was made in order to complete the aims of imperialist. Thus, it is important to ask a question, is the law relevant with Indonesia current situation? Is the law 
provide the justice sense of Indonesian as stated in the fifth sila of Pancasila, "social justice for all Indonesian".

Indonesia is a unitary state which consist of thousands of islands and tribes, that every tribes has their own customs and local wisdoms. However, through the "Youth Pledge" in October $28^{\text {th }}$ of 1928 were bounded by the pledge that state is one nation, one language and one blood. And finally, the purpose was thrived by Indonesian Independence Declaration in August $17^{\text {th }}$ of 1945. Even tough has been independent for 70 years, in reality Indonesia remains use the imperialist's law

Regarding law, it is necessary to talk about the society, since the law itself bound with its society. As a theory stated by the Carl Von Savigne, in which according to him "das rechtwirdnichtgemscht, estist und wirdmit demvolke" or in English "the law was not made but growth and develop with society. Therefore, in view of the laws, the society has to be the ultimate consideration. The law should be made in order for the people interest, not the king. Thus, the existing laws should able to give the justice sense for all people. Restorative justice (justice based on deliberation) is a major approach, in this time, according to Law Number 11 of 2012 on the Children Criminal Justice System, should be taken in order to cope the children that has conflict with law. This approach pointing out on the creation of just and balance condition for the offender and victim. Mechanism and criminal justice system focus on imprisonment shifted to the dialog and mediation process to create an agreement to cope crimes in justice and balance for both parties. Thus, this work will examine on how is the concept and implementation restorative justice over the restorative justice system to reduce criminals.

\section{METHOD}

This research was applied normative legal research which used several approaches in this matter is statute and conceptual approaches. Statute approaches was conducted by examine regulations for instance law on children protection and law on traffic. However, the conceptual approach refer to views and doctrines in the legal study specially in terms of criminal law and civil law. As normative legal research, this work applied secondary data that consist of primary, secondary and tertiary legal materials.

\section{ANALYSIS AND DISCUSSION}

\section{Concept and Implementation of Restorative Justice in Indonesia}

Indonesia criminal law system into a new phase and its process is one of the renewal is the adopted of restorative justice system that highlight of restitutive justice (focus on compensation). 
If we examine it in the perspective of legal development and modern imprisonment system, they have been conducting and announcing the system that known as "deor victim" relationshiprelation/victim approach. This approach has replace the old one that focus on the offenders or "daad daderstrafrecht". Legal scholar has introduce the justice formula especially in the human righst enforcement cases, that there are three approaches aspect to develop the legal system in the modernization framework and legal reform, namely legal structure, legal substance, and legal culture on which those all aspect should be run integral, simultaneously, and parallel. ${ }^{1}$ Below are several definitions of restorative justice: ${ }^{2}$

1) In a book with title Restorative Justice written by Eva Achjani Zulfa state that restorative justice is an approach in the 1960-ies to cope criminal cases. Restorative justice approach pointed out on the direct participation of offender, victim and society in the process of criminal cases. This is a difference between restorative justice and conventional criminal justice system thus this approach remains debatable. However, in reality this view developed and influenced of legal policy and legal practice in various state.

2) Tony Marshall, restorative justice is a process whereby parties with a stake in a specific offence collectively resolve how to deal with the aftermath of the offence and its implication for the future. ${ }^{3}$ In this matter, restorative justice is defined as a process in which all relevant parties in certain criminal act are involved to cope the case, to settle the problem and its consequences. According all definitions above, according to Eva Achjani Zulfa, tries to defined restorative justice a s a concept of justice attainment which focus on the restoration of crimes damages, which involving victim, offender, and society also related parties. Restoration in this matter not only for the victim but also towards the offender and society.

3) According to Muladi, restorative justice is a peace agreement between offender, victim and society, it become of restorative justice moral of ethics, therefore the just is conducted according to the Principle of Peace Justice. This principle reminds us that justice and peace are inseparable. Peace without justice is oppression, while justice without peace is the new form of persecution. ${ }^{4}$

4) B.E. Morrison ${ }^{5}$ Restorative justice is a from of conflict resolution and seeks to make it clear to the offender that the behavior is not condoned, at the same times as being supportive and respect of individual.

\footnotetext{
1 Https://Www.Mahkamaagung.Go.Id/Id/Artikel/2613/Keadilan-Restoratif-Sebagai-Tujuan-Pelaksanaan-Diversi-PadaSistem-Peradilan-Pidana-Anak. Diakses Pada 17 Januari 2020 Pukul 16:33 Wita.

${ }^{2}$ Eva Achjani Zulfa. (2009). Keadilan Restorative. Jakarta: Badan Penerbit FHUI. p.2.

${ }^{3}$ Ibid.p.5.

${ }^{4}$ Muladi dan Barda Nawawi Arief.(1984). Teori-Teori dan Kebijakan Pidana. Bandung:Alumni.p.77-78.

${ }^{5}$ B.E. Morrison, (2001). The School System : Developing its capacity in the regulation of a civil society, in J. Braithwaite \& H.Strang (Eds.), Restorative justice and Civil Society. Cambridge University Pers.p.195.
} 
The United Nations mentioned several principles that should be based of the restorative justice program, namely: ${ }^{6}$

1) That the response to crime should repair as much as possible the harm suffered by the victim. Settlement of a crime should be optimal to give a restoration for the victim. This principle is the main purpose in which restorative justice approach was used as a mindset of handling of criminal act. The settlement through restorative open an access for the victim to determine the settlement mechanism of a crime, since victim is the most suffer and most disadvantage of a crime. Therefore, on each steps should be shows up of the responsiveness of a mechanism for a victim needs, which lead to of restoration process or compensation for victim's losses. ${ }^{7}$

2) Thatoffenders should be brought tounderstand that their behavior is not acceptable and that it had same real consequences for the victim and community. Restorative justice approach can be taken only if the offender realized and recognized the mistake. In the restorative process, it is expected that the offender understands the mistakes and its consequences for the victim and society. This awareness could bring a voluntary responsibility of an offender. Voluntary should be understood as offender capability to introspect themselves or self-evaluation over the criminal acts, and they will be able to value and understand their acts correctly. In this matter the offender can be directed to realize the conducted crime is an unacceptable act, thus act is detriment the victim and offender as its consequence, offender responsibility should be considered as it should. ${ }^{8}$

3) That offenders can and should accept responsibility for their action; in terms of the offender realize their acts consequences, they will be charged to responsible before the damages which arise from their act. This is an objective of the restorative justice approach. Without the offender awareness, impossible to brought them voluntarily responsible of the acts. ${ }^{9}$

4) Thatvictimsshouldhaveaopportunitytoexpresstheirneedsandtoparticipateindetermining the best way for the offender to make reparation. This principle is related to the first one, in which of criminal handling mechanism through restorative justice open access to the victim has direct participation to solve the criminal act. Victim participation not mere to submit their charge before the compensation, because the victim has important position in influencing the process include evoking the offender awareness as mentioned by the second principle. The concept of dialogue that is promoted by this approach gives a sign of the interplay between the victim and the perpetrator in choosing the best solution as an effort to restore social relations between the two parties. ${ }^{10}$

\footnotetext{
${ }^{6}$ Handbook. (2006). On Restorative justice Programme. New York: United Nations. p. 8.

${ }^{7}$ Op cit.p. 15 .

${ }^{8}$ Ibid. P.16.

${ }^{9}$ Ibid. p. 17.

${ }^{10}$ Ibid.
} 
5) That the community has a responsibility to contribute to the process. restorative effort involves not only victims and perpetrators, but also the community. The community has a responsibility both in administering this process and in implementing the results of the agreement, so, in restorative efforts, the community can play a role as organizer, observer and facilitator. Directly or indirectly, the community is also part of the victims who are deserve for the benefit of the ongoing process. ${ }^{11}$

From explanation on restorative justice above, it can be concluded that restorative justice is a crime settlement mechanism beyond the court which aimed to get the justice by pointing out the restoration of victim and offender condition. Restoration means not mere the victim but also the offender. This process could re-harmonize the relationship between the offender and the victim.

Supposedly, the restorative justice system can be applied in accordance with the culture of a country. The existence of the restorative justice process as an alternative to solving criminal cases is very much determined by the culture of law in society, both from the community, including law enforcement officials. The current understanding of justice that seems emotional is only based on the punishment of the perpetrator, and does not consider the future impact. Indonesia as a country that upholds its communal nature allows the application of restorative justice as an effort to resolve criminal cases that may be resolved outside the criminal justice system. Restorative justice that we can see clearly in Indonesia is customary law that prioritizes deliberation between residents and the customary head if there is a violation in the customary territory. Criminal law becomes the second choice (ultimum remedium) for them if customary settlement does not find a solution. Not infrequently, indigenous peoples also ask victims for their responses regarding the obligations that should be given to the perpetrators for their mistakes. A system like this seems more human. This is what makes restoration justice seem to bring justice in the midst of the arid judicial process in Indonesia.

According to Muladi, the main goal of restorative justice is the justice achievement especially for all involved parties, not focusing on punishment. Justice is currently embraced, by the "abolosonos" called retributive justice, crime is defined as a person's violation over another. In addition, retributive justice is the view that the accountability of the perpetrator of a criminal act is formulated in the context of punishment, while restorative justice is of the view that the accountability of the perpetrator is formulated as an impact of understanding the act and to help decide which one is the best. In terms of its application, retributive justice tends to apply the suffering of imprisonment and prevention, while restorative justice applies retribution. ${ }^{12}$

\footnotetext{
${ }^{11}$ Ibid.p. 18

${ }^{12}$ Muladi. (1995). Kapita Selekta System Peradilan Pidana. Semarang: Badan Penerbit Universitas Diponegoro.p.24.
} 
Within the framework of restorative justice, putting aside the imprisonment, the court also can give several punishment, are: ${ }^{13}$

1) Reparation : this punishment was introduced in 1985, in the form of payment to the victim through court decision. Compensation only given to the victim for psychic loss and/or property.

2) Fines : In the event that the court imposes a fine, if there is a victim experiencing physical or psychological harm, the court must consider whether all or part of the fine will be given to the victim.

3) Community services: If the perpetrator has special qualifications and there are suitable job vacancies, the court can also impose a law in the form of social work in a community organization.

4) Periodical detention: Periodical detentions can be given to convicted persons who perform social work under the supervision of employees of the legal department.

5) Community Program: If the court considers that the perpetrator needs a special program to prevent them to repeat the crime, the court can impose a law whereby the perpetrator is required to participate in the program. For example, in a case of an accident that results in the death of another person where the driver is drunk, the court may ask the perpetrator to take an alcohol and drug conselling class.

According to Eva Achjanizulfa, restorative justice paradigm in handling criminal acts will bring lots of advantages or positive shift of community and nation. Several advantages as noted below: ${ }^{14}$

1. The community has been given the space to handle their own legal problems which they feel is fairer. In this case the principles of simplicity, clear and cash which are more widely known and used in customary law in the handling of civil cases can also be applied in criminal law. Moreover, basically Indonesian customary law does not recognize the difference between criminal case and civil case.

2. State's burden in several aspects could be reduces, for example:

a. The burden of dealing with crimes that can still be solved independently by the community. Police, prosecutors and courts can focus more on eradicating crimes with more dangerous qualificationssuchasnarcotics, terrorism, humantraffickingorgrosshumanrightsviolations.

b. Administratively, the number of cases that enter into judicial system could be reduced thus the institutional burden in this matter is court, as mentioned above decreased.

\footnotetext{
${ }^{13}$ http://www.justice.govti.nz/publicasion/publicasion-archived-1996/restorative-justice-discussion-paper 1996, retorative justice:A discussion paper-publiched1996,di akses pada tlg 18 januari 2020, pukul 12:40 wita. Dalam buku eva achjanizulfa. (2009). Keadilan restorative, Jakarta: badan penerbit FH UI.

${ }^{14}$ Pendapat eva achjanizulfa dalam tulisannya yang berjudul restorative justice di Indonesia (peluang dan tantangan penerapannya)
}

104 Ramdhani Abdul Hafidz, dkk| Effectivity Of Restorative Justice Meets ....... 
c. Burden to provide state budget for the judicial system, especially of department of correction budget that focus on criminal act settlement, ended with the imprisonment. This situation can increasing the problems in the correctional system. By the emerge of new form of sanction it is expected that they will be more effective and efficient (as it is developed in the Draft of Indonesia Criminal Law)

\section{Implementation of Restorative Justice in Indonesia}

Currently, restorative justice approach only implemented in the children has conflict with law cases. From those cases, can be seen that finding the central spots in order to make peace agreement between the offender and the victim. Thus, if agreement can be concluded between parties, it should be a priority by considering the above advantages. Restorative justice can be done over the cases that has the opportunity to create a middle-way. Below are implementing restorative justice before the children cases.

In the website of Indonesian Children Protection Commission, can be seen a written that says "prison is only appropriate for adults who have committed crimes. The child is not right to go to prison because it will destroy their hope for their future. He is an autonomous person who is growing, what is needed is help and guidance. Appropriate justice for the offender of the child is a restorative justice model, is to improve and care for the relationship between the perpetrator and the victim thus life harmony is maintained. The maximum punishment they can receive is forced education. This model will truly be realized if juvenile justice becomes a separate judicial system that is not part of the judicial system." 15

Children, due to all of its definitions has different characteristic to adult, this is the starting point for looking at the rights and obligations of a child which will also affect their position before the law. In the consideration of law number 11 of 2012 concerning the juvenile justice system, it is also stated that children are a mandate and a gift from the one and only God who has dignity as a whole human being. To maintain their dignity, children have the right to special protection, especially legal protection in the judicial system. According to Retnowulan Sutianto, child protection is part of national development. Protecting children is protecting humans, and building up the whole person. This is reflected in the essence of national development, namely the development of the whole Indonesian human being who is virtuous. Ignoring the issue of child protection means not strengthening national development. The result of the absence of child protection will cause various social problems that can disrupt law enforcement, order, security and national development. ${ }^{16}$

\footnotetext{
${ }^{15} \mathrm{http} / / /$ www.kpai.go.id/artikel/menuju-restorative-justice-dalam-sistem-peradilan-anak di akses pada tgl 18 januari 2020, pukul, 14:10 wita.

${ }^{16}$ Romli Atmasasmita. Peradilan Anak Di Indonesia.Bandung: Mandar Maju.p.166.
} 
Bagir Manan, in his book describes about restorative justice substance on the children cases, thus restorative justice aims are to restore of the criminal acts that conducted by children with the most-favour activity, victims and the environment which involving them directly, that should be a different approach with adults, and will be ended to the purpose of criminal law itself, according to Barda Nawawi Arif is "community protection" and offender individual coaching. ${ }^{17}$ In article 1 point 6 of law number 11 of 2012 concerning the juvenile justice system states, restorative justice is the settlement of criminal cases by involving the perpetrator, the victim, the family of the perpetrator / victim, and other related parties to jointly seek a fair settlement with emphasizes restoration to its original state, and not retaliation. The juvenile criminal justice system must prioritize the restorative justice approach, the juvenile criminal justice system, includes: ${ }^{18}$

a. Investigation and prosecution of children that implement according to the law, unless regulate differently.

b. Children court is conducted under general court procedure

c. Guidance, supervision and / or assistance during the process of implementing a criminal or criminal act and after undergoing a crime or action.

In the juvenile justice system as referred to in paragraph 2 letters a and $b$, it is mandatory to seek diversion, diversion is the transfer of the settlement of juvenile cases from the criminal justice process to the outside of the criminal justice process. An example of an accident case for the youngest of the Coordinating Minister for the Economy, Hatta Rajasa, (Rasyid). Rasyid's caused a deadly accident at KM 3.5 Tol Jagorawi, Tuesday $1^{\text {st }}$ of January 2013. Rasyid was driving a BMW X5 B 272 HR SUV crushed into a public transport Daihatsu Luxio F 1622 CY resulting in 2 deaths, namely Muhammad Raihan (1.5) and a grandfather of two grandchildren named Harun (57), and the 3 people were wound. The case did not processed in the court because the perpetrator tried to mediate with the victims and was willing to pay all the losses and treatment of the victims as well as compensation to the families left behind. This case shows that there is a restorative justice process trying to be build.

In the restorative justice implementation, Indonesia Police Officers in practice, often used unregulated method. Even though those practice undocumented officially. The possibility of a "deviation" has been recognized by experts. According to Romli Atmasasmita "in a democratic country it appears that the police apparatus is faced with these two conflicts of interest, the interest of maintaining order on the one hand and the interest of maintaining the principle of legality on the other. ${ }^{19}$

\footnotetext{
${ }^{17}$ Barda Nawawi. Bunga Rampai Kebijakan Hokum Pidana. Jakarta: PT. Kencana Prenada Group.p. 98

${ }^{18}$ Pasal 5 Ayat 1,2 Dan 3,Undang-Undang Nomor 11 Tahun 2012 Tentang System Peradilan Pidana Anak.

${ }^{19}$ Romli Atmasasmita.(2000). System Peradilan Pidana. Bandung: Putra Abardin.p.5.
} 
It should be noted that Restorative justice is not a principle, but a philosophy. The philosophy in the judicial process and also the philosophy of justice. Restorative justice is said to be a philosophy of justice because it is the basis for the preparation of judicial institutions. Thus, it can be interpreted that restorative justice is a series of processes which basically aims to restore (restore) the losses suffered by the victim. Justice in criminal law should aim to restore the situation to what it was before the crime occurred. When there are people who violate the law, the situation will change. So that is where the role of law is to protect the rights of every victim of crime. ${ }^{20}$

Restorative justice needs cooperation among stakeholders in order to create a condition where victim and offender could negotiate their conflict. Restorative justice restore the conflict between parties and also the community interest. Restorative justice also highlights on the human rights protection and recognize the impact of social injustice in the modest approach, and also to give formal justice towards the perpetrator and victim that not get any form of justice.

Restorative justice also put an effort to restore the victim security, respect on self-rights, dignity, and the most important is sense of control. ${ }^{21}$ Restorative justice system can be applied if the legal culture in a country requires restorative justice to be applied for a particular case. However, in my opinion, restorative justice is only applied to cases where the perpetrator and victim can get a middle ground or an agreement to make peace. However, for cases that close the gap, especially in big cases such as corruption, terrorism and narcotics, I think it cannot be applied because it involves many subjects and the losses suffered are not only experienced by the victim but also broadly, namely the "state". In my opinion, justice restoration is no longer a matter of mechanism but a sense of justice that can be felt by the community.

\section{CONCLUSION}

Restorative justice is not a principle but a philosophy, namely a philosophy in the judicial process and also a philosophy of justice, restorative justice is a series of judicial processes which basically aims to restore (recover) losses suffered by victims. Justice in criminal law should aim to restore the situation to what it was before the crime occurred. Restorative justice requires cooperative efforts from the community and government to create a condition where victims and perpetrators can recommend their conflict. Not always crimes committed by perpetrators are criminalize considering the condition of our penitentiary is not returning the perpetrator's condition to its original condition but will have a negative impact on the perpetrator, such as when leaving prison is not getting better, even getting worse than the previous situation.

\footnotetext{
${ }^{20}$ Mudzakir.(2013). Analisis Restorative Justice : Sejarah, Ruang Lingkup Penerapannya. Jakarta.p. 43.

${ }^{21}$ Zainal Abidin. (2005). Pemidanaan, Pidana dan Tidakan dalam Rancangan KUHP.Jakarta: Elsam. p13.
} 


\section{Bibliography}

\section{Books}

B.E. Morrison.(2001).The School System : Developing its capacity in the regulation of a civil society, in J. Braithwaite \& H.Strang (Eds.), Restorative justice and Civil Society. Cambridge University Pers.

Eva Achjani Zulfa.(2009).Keadilan Restorative. Jakarta: Badan Penerbit FH UI.

Muladi dan Barda Nawawi Arief. (2006). Teori-Teori dan Kebijakan Pidana. Bandung:Alumni. Handbook.(2006) Restorative justice Programme.New York:United Nations.

Muladi, 1995, kapita selekta system peradilan pidana. Semarang:Badan Penerbit Universitas Diponegoro.

Romli Atmasasmita.(1997).Peradilan Anak Di Indonesia. Bandung: Mandar Maju.

Barda Nawawi.(2008). Bunga Rampai Kebijakan Hokum Pidana. Jakarta: PT. Kencana Prenada Group.

Romli Atmasasmita. (2000). System Peradilan Pidana. Bandung: Putra Abardin.

Mudzakir. (2013). Analisis Restorative Justice : Sejarah, Ruang Lingkup Penerapannya, Jakarta.

Zainal Abidin. (2005). Pemidanaan, Pidana dan Tidakan dalam Rancangan KUHP. Jakarta: Elsam.

\section{Law and Regulation}

Indonesia, Undang Nomor 11 Tahun 2012 Tentang System Peradilan Pidana Anak.

World Wide Web

Https:/Www.Mahkamaagung.Go.Id/Id/Artikel/2613/Keadilan-Restoratif-Sebagai-TujuanPelaksanaan-Diversi-Pada-Sistem-Peradilan-Pidana-Anak. Diakses Pada 17 Januari 2020 Pukul 16:33 Wita

http://www.kpai.go.id/artikel/menuju-restorative-justice-dalam-sistem-peradilan-anak di akses pada tgl 18 januari 2020, pukul, 14:10 wita.

http://www.justice.govti.nz/publicasion/publicasion-archived-1996/restorative-justicediscussion-paper 1996,retorative justice:A discussion paper-publiched1996,di akses pada tlg 18 januari 2020, pukul 12:40 wita. Dalam buku,eva achjanizulfa. Keadilan restorative, Jakarta: badan penerbit FH UI, 2009. 